\title{
Wspomnienie o Kseni Starosielskiej
}

DOI: http://dx.doi.org/10.12775/RP.2019.023

\section{Język polski był dla niej nie tylko miłością, ale i całym życiem*}

Ksenia Starosielska. Zawsze uśmiechnięta, zawsze pełna energii, zawsze dzieląca się ciekawymi spostrzeżeniami. Taka zostanie w mojej pamięci. Taką Ją zapamiętam z kilku spotkań1, które dane mi było z Nią przeżyć, rozmów, które dane mi było z Nią przeprowadzić, e-maili, które dane mi było z Nią wymienić. Ksenia, zwana też przez przyjaciół Ksaną, odeszła 29 listopada 2017 roku w wieku 80 lat. Swoją twórczością przekładową na stałe wpisała się w relacje polsko-rosyjskie.

Anna Żebrowska mówiła o Kseni, że to nasz człowiek w Rosji i swój człowiek w Polsce (zob. Żebrowska, Starosielska 2009). A Grigorij Czchartiszwili (znany bardziej jako Boris Akunin) podkreślał, że polskiej literaturze w jej rosyjskim życiu dzięki Kseni Starosielskiej bardzo się poszczęściło (zob. ibid.). W jej przekładach ukazały się utwory pół setki polskich pisarzy, w tym Tadeusza Konwickiego, Tadeusza Różewicza, Pawła Huellego, Wiesława Myśliwskiego, Ryszarda Kapuścińskiego, Henryka Sienkiewicza, Jerzego Andrzejewskiego, Tadeusza Nowaka, Marka Hłaski, Stefana Chwina i Jerzego Pilcha. A pod jej redakcją w serii wydawanej przez Новое литературное обозрение - kilkadziesiąt pozycji współczesnej literatury polskiej.

Za swą pracę przekładową i popularyzatorską niejednokrotnie była wyróżniania, m.in. Krzyżem Kawalerskim Orderu Zasługi RP, nagrodą ZAiKS-u, nagrodą polskiego Pen Clubu, nagrodą Instytutu Książki. Dziękując za „Transatlantyk”, powiedziała, że brak jej słów, bo została wyróżniona za to, co jest szczęściem jej życia: „Przez całe życie robię to, co lubię, co uwielbiam, co kocham. I nie znudzi mi się to" (Ksenia... 2010). Rzeczywiście, tłumaczyła jedynie te książki, które polubiła i poczuła. Mówiła „To jest mój autor, chcę go przetłumaczyć” (Nocun 2017). Aby to zrobić, „wchodziła w skórę autora”, a że

* Zob. Proshchayte, Kseniya Yakovlevna 2017.

${ }^{1}$ Do kilku z tych spotkań nawiązałam w: Krajewska 2012. 
stosunkowo szybko wciągała ją materia tekstu, nie miała problemów z przestawianiem się na różne translatorskie tory (zob. Krajewska 2012: 58).

Anna Żebrowska żartobliwie zauważyła, że Ksenia Starosielska siedzi na tłumaczeniach niczym caryca Katarzyna II na tronie. Tłumaczka wówczas odpowiedziała: „Chętnie bym już z niego zeszła. Jak myślisz, po co otworzyłam seminarium dla młodych tłumaczy? Żeby było komu przekazać berło" (Żebrowska, Starosielska 2009). Przekładowe berło zostało przekazane m.in. przyjaciółce Kseni - Irinie Adelgejm.

Monika Krajewska Uniwersytet Mikołaja Kopernika w Toruniu monika.krajewska@umk.pl

\section{Przerwana rozmowa}

W lutym 2019 roku z okazji rocznicy urodzin Kseni Jakowlewny moskiewskie wydawnictwo Tekst opublikowało zbiór opowiadań Idy Fink Odpływajacy ogród /Упльвающий сад/. Rosyjskojęzyczne wydanie książki zrodziło się z bólu, jaki pozostał po nagłej śmierci Kseni Starosielskiej w sercach znającego Ją (dłużej lub całkiem krótko) i kochającego młodszego pokolenia tłumaczy literatury polskiej.

Członkowie seminarium przekładowego, które Ksenia założyła i przez osiemnaście lat prowadziła (skład zmieniał się na przestrzeni lat), praktycznie od razu postanowili, że właśnie w ten sposób powinni uczcić Jej pamięć. Kiedy wybór padł na zbiór opowiadań Idy Fink, okazało się, że w swoim czasie Ksenia przetłumaczyła z niego dla czasopisma Лехаим trzy teksty. Uczniowie uznali to za dobry znak - w ten sposób i Ona będzie razem $\mathrm{z}$ nimi obecna w książce.

Nie byłam uczestniczką seminarium, Ksenia Jakowlewna uznała, że nie jest mi potrzebne - do czasu jego powstania miałam już kilkuletnie doświadczenie w pracy przekładowej. Moim „seminarium” była dwudziestoletnia przyjaźń z Nią. Jestem jednak wdzięczna, że mogłam brać udział w powstawaniu książki w roli jej redaktora. To (jak i wcześniejsze zamknięcie niedokończonego przez Ksenię przekładu Na wschód od Arbatu /K востоку om Apбama/ Hanny Krall) dawało iluzję (a może nie tylko iluzję) kontynuacji przerwanej rozmowy...

Irina Adelgejm 


\section{Literatura}

Krajewska M., 2012, Gdańsk - Moskwa - Kraków. Spotkania z Ksenią Starosielską, „Przekładaniec”, 26, s. 53-67.

Ksenia Starosielska laureatką Transatlantyku 2008, 2010, https://ksiazki.wp.pl/ ksenia-starosielska-laureatka-transatlantyku-2008-6146199412902017a (dostęp: 15.07.2019).

Nocuń M., 2017, Pani Ksenia, https://inosmi.ru/social/20171208/240945905. html (dostęp: 15.07.2019).

Proshchayte, Kseniya Yakovlevna, 2017, https://culture.pl/ru/article/proshchayte-kseniya-yakovlevna (dostęp: 15.07.2019) [Прощайте, Ксения Яковлевна, 2017, https://culture.pl/ru/article/proshchayte-kseniya-yakovlevna].

Żebrowska A., Starosielska K., 2009, Kwestia taboretu, https://khanka.livejournal.com/18858.html (dostęp: 15.07.2019). 